\section{PENGAJARAN SASTRA BAHASA JERMAN DI SEKOLAH MENENGAH ATAS (SMA)}

\author{
Nurfadilla', Syamsu Rijal ${ }^{2}$, Misnawaty Usman ${ }^{3}$ \\ Universitas Negeri Makassar \\ Email:nurfadillaali22@gmail.com
}

Abstrak. Penelitian ini adalah penelitian deskriptif kualitatif. Penelitian ini bertujuan untuk memperoleh informasi mengenai tema-tema karya sastra dan jenis karya sastra yang relevan diajarkan di sekolah. Sumber data dalam penelitian ini adalah sumber data Primer dan Sekunder. Teknik pengumpulan data yang digunakan dalam penelitian ini adalah teknik pustaka. Data yang diperoleh kemudian di analisis menggunakan metode pembacaan heuristic dan hermeneutic. Hasil analisis data menunjukkan bahwa tema-tema karya sastra Bahasa Jerman yang relevan untuk di ajarkan pada siswa yaitu tema keluarga, kehidupan sehari-hari, ketuhanan, alam, dan kesehatan dengan memperhatikan level Bahasa siswa. Jenisjenis karya sastra yang relevan untuk diajarkan kepada siswa berdasarkan hasil penelitian di atas adalah Lirik dan Cerpen.

Kata Kunci: Pengajaran, Sastra, Sekolah

\section{INTERFERENCE}

Journal of Language,

Literature, and

Linguistics

\section{E-ISSN: 2721-1835 \\ P-ISSN: 2721-1827}

Submitted: Juny $30^{\text {th }}, 2020$

Accepted : August $4^{\text {th }}, 2020$

Abstract. This research is a descriptive qualitative research. It aims to obtain information on the relevant themes and types of literary works taught in school. Data seurcesof this research were primary and secondary data. Data collecting, the researcher used library technique. The data obtained were then analyzed using the heuristic and hermeneutic reading methods. The findings show that the relevant themes of German literary work that can be used in teaching are family, daily life, divinity, nature, and health by paying attention to the level of students' language skill. As for the types of German literary works based on the findings, the relevant types are Lyrics and Short Stories. 


\section{PENDAHULUAN}

Perkembangan zaman menuntut manusia untuk ikut berkembang dan salah satu aspek perkembangan yang menjadi tuntutan adalah komunikasi. Seseorang berkomunikasi dengan individu lain menggunakan bahasa. Bahasa merupakan media yang sangat penting dalam berkomunikasi untuk menyampaikan informasi, ide atau gagasan yang dapat mempererat hubungan sosial antar individu. Kemampuan berbahasa merupakan tuntutan yang sangat penting di era komunikasi global, khususnya penguasaan bahasa asing, sebab dengan penguasaan bahasa asing yang baik perkembangan informasi dan teknologi dunia dapat diketahui dan diikuti perkembangannya.

Pembelajaran sastra sebagai bagian dari pembelajaran bahasa Jerman di sekolah memiliki peran yang sangat penting selain membantu menambah pemahaman mengenai suatu budaya juga untuk membantu membentuk karakter siswa. Melalui pembelajaran sastra, pengetahuan budaya, cipta dan rasa, serta watak siswa dapat lebih berkembang.Berdasarkan Kurikulum 2013, kegiatan mengapresiasi karya sastra bertujuan agar siswa dapat mengenal atau memahami sastra serta dapat mengomunikasikannya baik secara lisan maupun tertulis. Hal ini berarti pembelajaran sastra dalam kurikulum dilakukan dalam konteks keterampilan berbahasa yang menggunakan materi sastra.

Banyaknya manfaat yang akan didapatkan melalui karya sastra membuat pembelajaran ini sangat penting untuk diajarkan sejak dini. Akan tetapi, pentingnya mempelajari sastra tidak berbanding lurus dengan penerapannya di sekolah. Pembelajaran sastra dipandang sebelah mata oleh para guru. Guru cenderung mengabaikan pembelajaran sastra dan hanya dilaksanakan sekadar memenuhi tuntutan kurikulum. Hal ini menyebabkan belajar sastra yang seharusnya menarik menjadi hal yang biasa saja, membosankan, memusingkan, dan akhirnya membuat siswa tidak menyukai karya sastra.

Seperti yang diungkap Sarjono (2017) bahwa telah terjadi disorientasi dalam pengajaran sastra di sekolah. Menurutnya, kegagalan pengajaran sastra di sekolah lebih banyak terjadi akibat kesalahan guru di sekolah yang telah mengingkari hakikat yang melandasi lahirnya pengajaran sastra. Berdasarkan pendapat tersebut tergambar bahwa pembelajaran sastra yang semakin di anak tirikan tidak terlepas dari peran seorang guru. Sebagai pendidik, guru seharusnya mampu meyakinkan dan menumbuhkan kegemaran bersastra kepada siswanya.

Bantuan stimulus yang diberikan oleh guru setidaknya akan menjadi masukan yang berarti dan mampu mengubah paradigma mengenai sastra yang membosankan. Oleh karena itu, guru Bahasa Jerman memiliki peran dan tugas yang lebih berat dari hanya sekadar mengajar dan meminta siswa mengerjakan tugas tetapi guru harus membantu siswa mengembangkan kemampuannya dalam mengapresiasi karya sastra baik secara lisan maupun tertulis.

Kemampuan mengapresiasi sastra secara lisan pada pembelajaran di sekolah cenderung diabaikan. Kegiatan mengapresiasi secara lisan biasanya hanya dilakukan pada materi prosa atau pantun. Pada pengapresiasian kutipan novel, hampir tidak ada guru yang menerapkannya karena dianggap bahwa tingkat kesulitan dalam mengartikan sebuah novel berbahasa Jerman sangatlah tinggi. Hal 
ini membuat kemampuan siswa dalam mengapresiasi puisi secara lisan ataupun tulisan tidak dikembangkan dengan baik oleh guru. pengetahuan tentang sastra termasuk apresiasi sastra, di nomor duakan dan dianggap hanya sebagai hiburan. Kondisi inilah yang kemudian menyebabkan guru bermalas-malasan dalam mengajarkan pengetahuan tentang sastra.

Padahal dengan mengapresiasi karya sastra lisan dan tulisan akan banyak bermanfaat bagi siswa seperti mengetahui kemenarikan suatu karya dari sudut pandang yang berbeda, memberikan pembelajaran mengenai nilai-nilai kesopanan dan nilai budaya yang terkandung dalam sebuah karya sastra, membantu mengetahui budaya suatu negara yang terkandung dalam karya sastra, serta membantu meningkatkan kemampuan berbahasa Jerman siswa. Tidak hanya itu, dengan mengapresiasi karya sastra secara lisan dan tulisan sedikit banyak akan menumbuhkan minat siswa dalam mempelajari karya sastra.

Kesulitan guru dalam mengajarkan sebuah karya sastra di sekolah membuat penulis tertarik untuk mengangkatkan permasalahan ini dalam sebuah penelitian. Dimana penulis menyarankan guru Bahasa Jerman mengenai pentingnya pengajaran sastra di Sekolah. Peneliti meyakini bahwa pengajaran sastra sangat berpengaruh terhadap nilai moral, pemahaman budaya dan keterampilan berbahasa siswa. Hal ini dibuktikan dengan beberapa penelitian yang relevan dengan penelitian yang akan dilakukan oleh peneliti.

Hidayat (2009) dari Prodi Pendidikan Bahasa dan Sastra Indonesia STAIN Purwokerto. Dalam penelitian ini dikatakan bahwa ada empat faktor yang mendukung keberhasilan pembelajaran Sastra di Sekolah yaitu faktor kurikulum. faktor guru, faktor siswa serta faktor sarana dan prasara. Ninawati (2017) dari prodi Pendidikan Bahasa dan Sastra Indonesia Universitas Jember. Dalam penelitian ini dikatakan bahwa siswa perlu dibimbing untuk mengenal sastra secara menyenangkan dan menanamkan kerinduan. Wulandari (2015) dari Pendidikan Bahasa dan Sastra Indonesia Universitas Negeri Medan. Dalam penelitian ini dikatakan bahwa sastra sangat berperan dalam pendidikan karakter peserta didik (manusia), yaitu dalam perkembangan bahasa, perkembangan, kognitif, perkembangan kepribadian, dan perkembangan sosial.

\section{Pembelajaran Lintas Budaya}

Pembelajaran interkultural atau dalam konteks Jerman dikenal dengan istilah interkulturelles Lernen merupakan salah satu bentuk pembelajaran sosial dengan tujuan untuk memupuk kompetensi antarbudaya atau interkulturelle Kompetenz para peserta didik.

\section{Pengertian Sastra}

Sastra merupakan ungkapan pribadi manusia yang berupa pengalaman, pemikiran, perasaan, ide, semangat, keyakinan dalam suatu bentuk gambaran konkret yang membangkitkan pesona dengan alat bahasa. Menurut pandangan Sugihastuti (2007: 81-82) karya sastra merupakan media yang digunakan oleh pengarang untuk menyampaikan gagasan-gagasan dan pengalamannya. Sebagai media, peran karya sastra sebagai media untuk menghubungkan pikiran-pikiran pengarang untuk disampaikan kepada pembaca. Selain itu, karya sastra juga dapat 
merefleksikan pandangan pengarang terhadap berbagai masalah yang diamati di lingkungannya

\section{Jenis - Jenis Karya Sastra}

1. Puisi

Puisi adalah salah satu karya sastra yang disusun untuk mengekpresikan ide, gagasan, perasaan dan emosi penyair dengan menggunakan kata-kata yang indah, melebihi Bahasa yang digunakan sehari-hari. Puisi terbagi menjadi 3 yaitu:

a. Epik adalah merupakan sebuah cerita panjang yang berbentuk syair (puisi) yang berisi cerita kepahlawanan baik kepahlawanan yang berhubungan dengan legenda, kepercayaan, maupun sejarah.

b. Lirik merupakan puisi yang bersifat subjektif dan personal, artinya penyair menceritakan masalah-masalah yang bersumber dari dalam dirinya. Puisi ini bentuknya agak pendek dan biasanya menggunakan kata ganti orang pertama.

c. Dramatik ialah puisi yang memiliki persyaratan dramatik yang menekankan tukaian emosional atau situasi yang tegang umumnya secara objektif menggambarkan perilaku seseorang, baik lewat lakuan atau dialog maupun monolog.

2. Prosa

Prosa adalah suatu karya sastra yang bentuknya tulisan bebas dan tidak terikat dengan berbagai aturan dalam menulis seperti rima, diksi, irama, dan lain sebagainya. Prosa terbagi atas 3 yaitu:

a. Novel merupakan salah satu jenis karya sastra berbentuk prosa. Salah satu bentuk prosa itu menyajikan sisi kehidupan manusia secara luas. Keluasannya mengakibatkan novel dikatakan sebagai narasi yang panjang.

b. Cerpen adalah sebuah karangan berbentuk prosa fiksi yang habis dibaca sekali duduk, maksud dari habis dibaca sekali duduk adalah tidak membutuhkan waktu yang berlama-lama untuk menyelesaikan satu cerita.

c. Novelet adalah salah satu bentuk karya sastra yang berbentuk karya prosafiksi yang panjangnya cukupan, tidak terlalu panjang, namun juga tidak terlalu pendek .

3. Drama

Drama adalah karya sastra yang disusun untuk melukiskan hidup berupa rangkaian dialog yang menciptakan atau tercipta dari konflik batin atau fisik dan memiliki kemungkinan untuk dipentaskan.

\section{Hakikat Pembelajaran \\ Pengertian Pembelajaran}

Pembelajaran adalah suatu perubahan dari peristiwa atau situasi yang dirancang sedemikian rupa dengan tujuan memberikan bantuan atau kemudahan dalam proses belajar mengajar sehingga bisa mencapai tujuan belajar. 


\section{Langkah - Langkah Pembelajaran Sastra}

Langkah-langkah model pembelajaran sastra sebagai berikut :

1. Pelacakan, pendahuluan guru perlu mempelajari karya sastra yang akan diajarkannya di dalam kelas. Hal tersebut dilakukan untuk memperoleh pemahaman awal tentang puisi yang akan disajikan sebagi bahan.

2. Penentuan sikap praktis untuk mempermudah siswa memahami karya sastra, guru harus memilih informasi apa yang seharusnya diberikan kepada siswa. Guru juga hendaknya memilih puisi yang tidak terlalu panjang agar dapat dibahas dalam sekali pertemuan.

3. Introduksi atau pengantar sangatlah penting dalam menciptakan suasana pembelajaran yang menyenangkan. Pemilihan introduksi yang tepat dapat dilakukan dengan melihat situasi siswa dan karakteristik karya sastra yang akan diajarkan.

4. Penyajian, agar karya sastra dapat memberikan kesan dan pesan bagi siswa, maka dibutuhkan penyajian yang tepat. Misalnya, dengan membacakan karya sastra dengan irama dan penghayatan yang tepat. Dengan demikian,siswa akan tersentuh dan tertarik untuk menelisik puisi lebih dalam lagi.

5. Diskusi untuk mencermati seberapa dalam apresiasi siswa terhadap karya sastra maka dapat diadakan diskusi. Siswa dapat membicarakan unsur-unsur intrinsic dan ekstrinsik dari karya sastra.

Pengukuhan dapat dilakukan dengan cara memberikan tugas-tugas di luar kelas yang merupakan kelanjutan dari pembelajaran di dalam kelas.

\section{METODE}

Penelitian ini menggunakan pendekatan kualitatif, dimana pendekatan kualitatif adalah pendekatan yang dilakukan secara utuh kepada subjek penelitian yang terdapat sebuah peristiwa dan peneliti menjadi instrumen kunci dalam penelitian ini, hasil pendekatan tersebut diuraikan dalam bentuk kata-kata yang tertulis (empiris) yang telah diperoleh dan dalam pendekatan ini pun lebih menekankan makna dari pada generalisasi.

Objek dalam penelitian ini adalah nilai-nilai sebuah karya sastra yang banyak memberikan manfaat bagi siswa. Sumber data merupakan tempat ditemukannya data yang akan ditulis. Adapun sumber data dalam penelitian ini berupa sumber data primer dan sekunder. Untuk mengumpulkan data, penulis menggunakan teknik pustaka yaitu dengan menganalisis isi. Datanya berupa karya sastra, maka peneliti mencoba menelaah isi karya sastra. Adapun langkah-langkah pengumpulan data dalam karya sastra yaitu:1. Membaca secara cermat karya sastra yang akan diteliti, 2 . mencatat kalimat yang menggambarkan adanya nilai-nilai edukatif dalam karya sastra, 3. Menganalisis nilai Edukatif dalam karya sastra.

Tahap pertama analisis data dalam penelitian ini adalah pembacaan heuristic yaitu penulis menginterprestasikan teks karya sastra. Caranya yaitu membaca dengan membaca cermat dan teliti tiap kata dan kalimat dalam karya sastra guna analisis struktur. Selain itu, pembaca heuristic digunakan untuk menemukan nilai-nilai edukatif dalam karya sastra. Tahap kedua penulis melakukan pembacaan hermeneutic yakni dengan menafsirkan makna peristiwa atau kejadian- 
kejadian yang terdapat dalam teks karya sastra hingga dapat menemukan nilai-nilai eduaktif dalam cerita tersebut.

Teknik penyimpulan menggunakan metode penyajian formal, merupakan metode penyajian data berupa perumusan dengan kata-kata yang sesuai dengan Kamus Besar Bahasa Indonesia (KBBI).

\section{HASIL DAN PEMBAHASAN}

Setelah menganalisis data dengan pembacaan heuristic dan pembacaan hermeneutic ditemukan bahwa tema karya sastra yang relevan diajarkan kepda siswa khususnya pada tingkat Sekolah Menengah Atas (SMA) yaitu tema keluarga, kehidupan sehari-hari, ketuhanan, alam, dan kesehatan dengan memperhatikan level Bahasa siswa. Serta jenis-jenis karya sastra yang relevan untuk diajarkan kepada siswa berdasarkan hasil penelitian di atas adalah Lirik dan Cerpen.

Hal ini berdasarkan pendapat Herfanda (2007: 4) merumuskan bahwa secara garis besar tujuan pembelajaran sastra dapat dikelompokkan menjadi dua. Pertama, tujuan ideal yang bersifat jangka panjang untuk membentuk karakter siswa. Rincian dari tujuan ini, antara lain, (1) membentuk karakter siswa agar memiliki rasa keindahan dan peduli pada masalah-masalah keindahan; (2) menumbuhkan sifat-sifat mulia pada diri siswa, seperti kearifan, kesantunan, kerendah-hatian, ketuhanan, keadilan dan kepedulian pada nasib sesama; (3) mewariskan nilai-nilai luhur budaya bangsa untuk membentuk jati diri siswa sekaligus jati diri bangsa; (4) menumbuhkan sikap apresiatif terhadap karya sastra, dan (5) menumbuhkan minat baca terhadap karya sastra. Kedua, tujuan praktis yang bersifat jangka pendek sesuai dengan yang tertera pada kurikulum.

Dari pendapat tersebut dikatakan bahwa karya sastra yang baik untuk diajarkan kepada siswa adalah karya sastra yang menumbuhkan sifat-sifat mulia pada diri siswa, seperti kearifan, kesantunan, kerendah-hatian, ketuhanan, keadilan dan kepedulian pada nasib sesama. Selanjutnya hal lain yang menjadi alasan penulis adalah berdasar pada pendapat Rusyana dan Suryaman (2005, dalam Suryaman 2010) menyatakan di dalam pembelajaran bersastra dikehendaki terjadinya kegiatan bersastra, yaitu kegiatan menggunakan bahasa dan estetika. Jadi, berbagai unsur sastra, seperti tokoh, penokohan, alur cerita, latar cerita di dalam prosa; unsur bentuk dan makna di dalam puisi; dialog dan teks pelengkap di dalam drama tidaklah diajarkan secara berdiri sendiri sebagai unsur-unsur yang terpisah, melainkan dalam susunan yang padu sebagai karya cipta yang indah di dalam kegiatan mendengarkan, kegiatan berbicara, kegiatan membaca, dan kegiatan menulis. Dalam pendapat tersebut sangat jelas dikatakan adanya pengajaran prosa dan puisi serta dialog atau teks sastra yang bisa berupa cerpen yang dikehendaki untuk diajarkan agar terjadi kegiatan bersastra.

\section{SIMPULAN}

Berdasarkan hasil penelitian yang diperoleh, maka dapat disimpulkan bahwa tema-tema karya sastra yang relevan diajarkan yaitu tema keluarga, kehidupan sehari-hari, ketuhanan, alam, dan kesehatan dengan memperhatikan level bahasa siswa kemudian jenis-jenis karya sastra yang relevan untuk diajarkan kepada siswa berdasarkan hasil penelitian di atas adalah Lirik dan Cerpen. 
Agar siswa lebih tertarik dalam mempelajari karya sastra maka disarankan:

1. Bagi sekolah, mendukung peningkatan kualitas pendidikan, dengan memenuhi kebutuhan guru dalam mengajar terutama dalam mengajar bahasa.

2. Bagi guru, guru diharapkan untuk tidak ragu mengajarkan karya sastra karena dalam karya sastra banyak hal yang bisa dipelajari oleh siswa. Hal yang bisa dipelajari siswa dalam karya sastra yaitu budaya dari suatu negara, nilai-nilai moral dan dapat membantu meningkatkan kemampuan berbahasa siswa.

Bagi Penelitian Selanjutnya, diharapkan dalam penelitian selanjutnya untuk mencari karya-karya sastra yang lain untuk disarankan kepada guru-guru bahasa Jerman guna melengkapi penelitian ini. Manurut pendapat penulis masih banyak karya sastra bahasa Jerman yang cocok diajarkan kepada siswa karena terdapat pelajaran budaya, nilai moral dan dapat membantu meningkatkan kemampuan berbahasa siswa.

\section{DAFTAR PUSTAKA}

Hidayat, A. (2009). Pembelajaran Sastra di Sekolah. Jurnal Pemikiran Alternatif Kependidikan, hal, 1, 3-5. Universitas Muhammadiyah Purwekerto

Herfanda, A. Y. (2007). Menuju Format Baru Pengajaran Sastra, Makalah Seminar Pengajaran Bahasa dan Sastra dalam Gebyar Bahasa dan Sastra Indonesia 2007, HMBSI FPBS UPI Bandung, 10 April 2007.

Sugihastuti. (2007). Teori Apresiasi Sastra. Yogyakarta : Pustaka Pelajar.

Sarjono, Agus R., dan Damshäuser, B. (2017). Johan Wolfgang von Goethe: Telah Berpilin Timur dan Barat. Hal 70-74. Depok : Komodo Books Setiyadi. 2014. Perbedaan pengaruh Pembelajaran CIRC dan Reproduksi puisi

terhadap kemampuan menulis puisi siswa kelas VIII SMP, Hal 32-34. Skripsi.Universitas Muhammadiyah Purwokerto.

Suryaman , M. (2010). Pendidikan Karakter Melalu Pembelajaran Sastra. FBS Cakrawala Pendidikan, Mei 2010, Th. XXIX, Edisi Khusus Dies Natalis UNY

Syahrul, N. (2017). Pembelajaran Sastra Indonesia dalam Konteks Global. hal, 206.Skripsi. Jawa Timur: PBSI FKIP Universitas Jember

Wulandari, R. A. (2015). Sastra Dalam Pembentukan Karakter Siswa. Jurnal Edukasi Kultura Vol.2 No.2, hal, 71. Pendidikan Bahasa dan Sastra Indonesia Universitas Negeri Medan. 